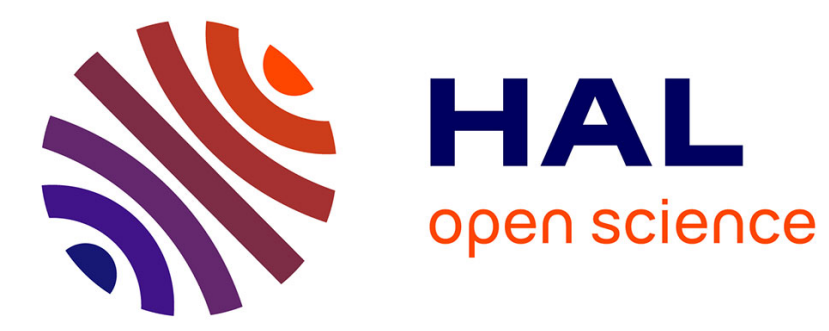

\title{
Characterisation of clinical and food animal isolates producing CTX-M-15 extended-spectrum $\beta$-lactamase belonging to ST410 phylogroup A
}

Lorena López-Cerero, Pilar Egea, Lara Serrano, Dolores Navarro, Azucena Mora, Jorge Blanco, Yohei Doi, David L. Paterson, Jesús Rodríguez-Baño, Alvaro Pascual

\section{To cite this version:}

Lorena López-Cerero, Pilar Egea, Lara Serrano, Dolores Navarro, Azucena Mora, et al.. Characterisation of clinical and food animal isolates producing CTX-M-15 extended-spectrum $\beta$-lactamase belonging to ST410 phylogroup A. International Journal of Antimicrobial Agents, 2011, 37 (4), pp.365. 10.1016/j.ijantimicag.2011.01.001 . hal-00679592

\section{HAL Id: hal-00679592 https://hal.science/hal-00679592}

Submitted on 16 Mar 2012

HAL is a multi-disciplinary open access archive for the deposit and dissemination of scientific research documents, whether they are published or not. The documents may come from teaching and research institutions in France or abroad, or from public or private research centers.
L'archive ouverte pluridisciplinaire HAL, est destinée au dépôt et à la diffusion de documents scientifiques de niveau recherche, publiés ou non, émanant des établissements d'enseignement et de recherche français ou étrangers, des laboratoires publics ou privés. 


\section{Accepted Manuscript}

Title: Characterisation of clinical and food animal Escherichia coli isolates producing CTX-M-15 extended-spectrum $\beta$-lactamase belonging to ST410 phylogroup A

Authors: Lorena López-Cerero, Pilar Egea, Lara Serrano, Dolores Navarro, Azucena Mora, Jorge Blanco, Yohei Doi,

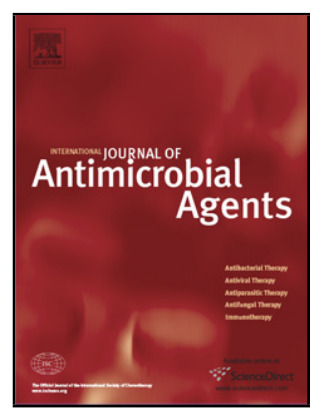

David L. Paterson, Jesús Rodríguez-Baño, Alvaro Pascual

PII:

DOI:

Reference:

S0924-8579(11)00014-8

ANTAGE 3516

To appear in: International Journal of Antimicrobial Agents

Received date: $\quad 30-8-2010$

Revised date: $\quad 29-11-2010$

Accepted date: $\quad 11-1-2011$

Please cite this article as: López-Cerero L, Egea P, Serrano L, Navarro D, Mora A, Blanco J, Doi Y, Paterson DL, Rodríguez-Baño J, Pascual A, Characterisation of clinical and food animal Escherichia coli isolates producing CTX-M-15 extended-spectrum $\beta$ lactamase belonging to ST410 phylogroup A, International Journal of Antimicrobial Agents (2010), doi:10.1016/j.ijantimicag.2011.01.001

This is a PDF file of an unedited manuscript that has been accepted for publication. As a service to our customers we are providing this early version of the manuscript. The manuscript will undergo copyediting, typesetting, and review of the resulting proof before it is published in its final form. Please note that during the production process errors may be discovered which could affect the content, and all legal disclaimers that apply to the journal pertain. 


\section{Characterisation of clinical and food animal Escherichia coli isolates producing $\mathrm{CTX}-\mathrm{M}-15$ extended-spectrum $\beta$-lactamase belonging to ST410 phylogroup $A$ *}

Lorena López-Cerero ${ }^{a, \star}$, Pilar Egea ${ }^{a}$, Lara Serrano ${ }^{a}$, Dolores Navarro ${ }^{a}$, Azucena Mora $^{c}$, Jorge Blanco ${ }^{c}$, Yohei Doi ${ }^{d}$, David L. Paterson ${ }^{e}$, Jesús Rodríguez-Baño ${ }^{a, f}$, Alvaro Pascual ${ }^{a, b}$

${ }^{a}$ University Hospital Virgen Macarena, Seville, Spain

${ }^{\mathrm{b}}$ Microbiology Department of School of Medicine, University of Seville, Seville, Spain

${ }^{\mathrm{c}}$ Escherichia coli Reference Laboratory, Department of Microbiology and

Parasitology, Faculty of Veterinary Science, University of Santiago de Compostela, Lugo, Spain

d Division of Infectious Diseases, University of Pittsburgh Medical Center, Pittsburgh, $P A$, USA

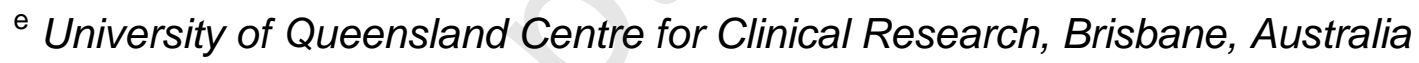

${ }^{\dagger}$ Internal Medicine Department, School of Medicine, University of Seville, Seville, Spain

\section{ARTICLE INFO}

Article history:

Received 30 August 2010

Accepted 30 November 2010

Keywords: 


\section{CTX-M-15}

Phylogroup A

Meat

ST410

* Corresponding author. Tel.: +34 955 008138; fax: +34 955011584.

E-mail address: llopez@us.es (L. López-Cerero).

*Part of this work has been presented as a poster at the Interscience Conference on Antimicrobial Agents and Chemotherapy (ICAAC), 12-15 September 2009, San Francisco, CA. 


\section{ABSTRACT}

Seven phylogroup A CTX-M-15-producing Escherichia coli isolates recovered from clinical and meat samples were further characterised. All of them belonged to sequence type ST410. Only 2 of the 22 virulence genes investigated were detected. All isolates carried the $\mathrm{fimH}$ gene encoding type 1 fimbriae, and five isolates harboured the iucD gene encoding aerobactin siderophore. A group of five isolates showed $81.2 \%$ similarity by pulsed-field gel electrophoresis (PFGE), comprising three clinical isolates belonging to ONT:H9 and two food isolates belonging to O55:H9.

Different Hpal digestion patterns were observed for plasmids, but all of them belonged to IncFIB group and harboured bla $a_{\mathrm{CTX}-\mathrm{M}-15}$ associated with bla tetA, catB3 and $\operatorname{aac}\left(6^{\prime}\right)-1 b$ surrounded by an identical genetic environment. These findings showed the possibility of lateral gene transfer of bla antibiotic resistance determinants between low-virulence food and clinical isolates. 


\section{Introduction}

During the last decade, CTX-M-type extended-spectrum $\beta$-lactamases (ESBLs) have replaced TEM- and SHV-type ESBLs worldwide as the most common cause of resistance to expanded-spectrum cephalosporins. Recently, a multiresistant clone of CTX-M-15-producing Escherichia coli (B2 O25b:H4/ST131) has been reported as spreading all over the world [1]. In the Health Area of the Virgen Macarena Hospital in the north of Seville (Spain), the predominant enzyme among ESBL-producing $E$. coli is CTX-M-14 [2]. However, the emergence of CTX-M-15 was noted in October 2005 and multidrug-resistant CTX-M-15-producing E. coli accounted for $24 \%$ of all ESBL-producers in 2007 [3]. CTX-M-15 production has mainly been found among phylogroup B2 clinical isolates, although clinical and food-producing animal isolates belonging to group $A$ have also been detected $[2,3]$. The aims of this study were to analyse the genetic relatedness of phylogenetic group $A$ isolates, their serotypes and virulence genes, and the genetic environment of their plasmid-acquired blacTX-M-15 genes

\section{Material and methods}

\subsection{Bacterial isolates}

Seven CTX-M-15-producing E. coli isolates belonging to phylogroup A were obtained during two studies of ESBL-producers [2,3] in the Seville area. One clinical isolate was obtained in October 2005, four clinical isolates were obtained between September and December 2006, all of which were from urine samples from non- 
related community patients, and two isolates were from raw turkey samples obtained in March 2007.

\subsection{Typing of isolates}

Molecular typing was carried out by Xbal pulsed-field gel electrophoresis (PFGE) (URL?), and multilocus sequence typing (MLST) was carried out according to the protocol specified on the Escherichia coli MLST website (http://mlst.ucc.ie/mlst/dbs/Ecoli). A dendrogram was produced by the unweighted pair group method with arithmetic mean (UPGMA) algorithm based on the Dice similarity coefficient with a $1.0 \%$ band position tolerance. Serotyping was performed with $\mathrm{O}$ and $\mathrm{H}$ antisera [1,4]. Virulence factors (papEF, papG, sfa/focDE, afa/draBC, fimH, fimA $v_{M T 78}, h l y A, c n f 1$, sat, cdtB, iucD, iroN, kpsMII, kpsMIII, neuC-K1, cvaC, iss, traT, ibeA, malX, usp and tsh) were analysed by polymerase chain reaction (PCR) [4].

\subsection{Analysis of the plasmid and genetic environment of bla ${ }_{C T X-M-15}$}

Mating experiments were carried out with $E$. coli strain $\mathrm{J} 53 \mathrm{Azi} \mathrm{i}^{\mathrm{R}}$ as well as transformation into $E$. coli $\mathrm{DH} 10$ by electroporation. Plasmids were extracted by the alkaline lysis method. Plasmid DNA from the transconjugants and electrotransformants was analysed using restriction of $\mathrm{S} 1$ nuclease, Hpal restriction and PCR-based replicon typing [5].

Genes associated with the multidrug resistance region harbouring bla CTX-M-15 $_{15}$ were sought in transconjugants and transformants by PCR using primers previously 
described for junction sequences 1-6 and resistance genes [6]. Other genes [aac(3)II and catB3-3] were screened using primer pairs designed for this study (aac3IIF, 5'TGCCTCACTTAAAGCGATTG-3'; aac3IIR, 5'-CAAGCATCGGCATCTCATAC-3'; catb3F, 5'-ATCTGTTTCCGGACCGTG-3'; and catb3R, 5'-

CTTTTGTCACCAACGAGCG-3'). In addition, Hpal-digested plasmid DNA from transformants and transconjugants was hybridised using blactX-M-15, $\operatorname{aac}\left(6^{\prime}\right)-I b$ and aac(3)-I/ probes. CTX-M-15-producing E. coli belonging to sequence type ST131 was used as a control strain [3].

The genetic environment of blaCTX-M-15 was investigated by PCR and sequencing using primers for upstream insertion elements IS26 [7] and ISEcp1 [7] and for the putative promoter region (bla/PF, 5'-GCCAGTGACATCGTCCCATTGACG-3'; and PR, 5'-TGCTCTGTGGATAACTTGCAGAG-3').

\section{Results}

The seven phylogroup A CTX-M-15-producing E. coli isolates belonged to ST410 and generated seven different pulsotypes by PFGE clustering with $69.7 \%$ similarity (Fig. 1). Five of the seven pulsotypes showed $81.2 \%$ similarity and formed two clusters (>85\% similarity) designated as I (isolates 281,316 and 358 ) and II (isolates 113-1 and 113-6). The remaining two pulsotypes were designated as III (isolate 338) and IV (isolate 267). PFGE cluster I contained three clinical isolates belonging to ONT:H9, whilst PFGE cluster II grouped two food isolates belonging to O55:H9. PFGE III and IV isolates showed the serotypes ONT:HNM and O20:H9, respectively. Only 2 of the 22 virulence genes investigated were detected. All isolates carried the 
fimH gene encoding type 1 fimbriae, and five isolates $(281,316,113-1,113-6$ and 267) additionally harboured the $i u c D$ gene encoding aerobactin siderophore.

Cefotaxime resistance was transferred from two strains by conjugation and from five strains by electroporation. The size of plasmids was estimated as being between 89 $\mathrm{kb}$ and $119 \mathrm{~kb}$, all of which belonged to the IncFIB group. Different Hpal digestion patterns were observed for plasmids obtained from isolates belonging to PFGE clusters I and II (Fig. 2).

The resistance determinants bla $a_{\mathrm{CTX}-\mathrm{M}-15}$, bla $a_{\mathrm{OXA}-1}, b / a_{\mathrm{TEM}}, \operatorname{tet} A, \operatorname{catB} 3$ and $\operatorname{aac}\left(6^{\prime}\right)-1 b$ as well as a partial sequence of transposon $\operatorname{Tn} 5403$ were detected in all transconjugants and transformants by PCR, however aac(3)-I/ yielded negative result by PCR and positive result by hybridisation. Southern hybridisation analysis showed that blaCTX-M15 was located on two or three high molecular weight fragments and that $\operatorname{aac}\left(6^{\prime}\right)-1 b$ (Fig. 2) and aac(3)-I/ probes hybridised with the larger fragment.

Sequence analysis revealed an identical genetic environment upstream of the bla M-15 gene for all four PFGE types: the transposase gene of IS26 was located 64 bp upstream of a partially truncated ISEcp1 (289 bp length), and all these sequences contained the putative promoter region for the bla gene (GenBank accession no. GU479916 for E. coli 113-1).

\section{Discussion}

These results show the presence of the bla $a_{\mathrm{CTX}-\mathrm{M}-15}$ gene in meat and human group $\mathrm{A}$

E. coli isolates from the same area located in related plasmids. The CTX-M-15 
enzyme has been widely described for $E$. coli from humans, specifically in isolates belonging to phylogroup B2 ST131 [1], but less so from animals. The bla has previously been detected in a clinical E. coli isolate from a cow [8], although contamination of retail meat by CTX-M-15-producing $E$. coli has not been reported. Whilst further studies are required to determine the relationship between infections caused by CTX-M-15 ESBL-producing group A isolates and the food chain, other bla genes such as CTX-M-9, CTX-M-14 and CTX-M-32 have been shown to be carried by poultry isolates with very similar PFGE profiles to those of clinical human isolates $[9,10]$

Dissemination of bla $\mathrm{CTX}_{\mathrm{C}-\mathrm{M}-15}$ among phylogroup $\mathrm{A}$ isolates, attributed as being most likely due to horizontal transfer between phylogroups $B_{2}$ and $A$, was recently described for a strain affecting 19 patients in a medical centre in Pittsburgh, PA [11]. A worrisome relationship between bla insertion elements has been observed $[6,12]$. In this study, the blacTX-M-15 gene in the phylogroup A isolates was co-transferred with other resistance markers in IncF group plasmids and clustered in the same fragment, as previously described for phylogroup B2 isolates [6,13]. IS26 was detected disrupting ISEcp1, as was the case for other bla epidemic ST131/B2 CTX-M-15-producing pulsotypes [6,12,14].

In contrast to clonal group ST131, in which all isolates show the same serotype (O25b:H4), the seven ST410 isolates of the present study belonged to four serotypes, although six of the seven isolates carried the same flagellar antigen H9. A similar phenomenon has been described in clonal uropathogenic isolates of ST69 
phylogroup D (serotypes O17:H18, O15:H18, O17:HNM, O25:H18, O73:H18, O77/17:H18, ONT:H18 and ONT:HNM) and ST95 phylogroup B2 (O1:H7, O2:H7 and O18:H7) [15].

Extraintestinal pathogenic $E$. coli harbour virulence genes required for successful pathogenic invasion of a human or animal host. The 22 virulence genes tested in the present study can be classified into at least five categories based on their function: adhesins (papEF, papG, sfa/focDE, afa/draBC, fimH, fimAv $v_{M T 78}$ ); toxins (hlyA, cnf1, sat, $c d t B$ ); siderophores (iucD, iroM); protectins (kpsMII, kpsMIII, neuC, cvaC, iss, $\operatorname{traT}$ ); and miscellaneous (ibeA, malX, usp, tsh). Only 2 of these 22 virulence genes were detected, namely the $f i m H$ gene encoding type 1 fimbriae and the iucD gene encoding aerobactin siderophore. The low virulence gene content detected suggests that the seven phylogroup A CTX-M-15-producing isolates characterised in this study may be opportunistic pathogens whose ability to cause disease can be limited to compromised hosts.

Limitations of this study include the small sample size of strains, as phylogroup A CTX-M-15-producing isolates are rarely found in surveys carried out in our area. Study strengths included the geographical matching and all isolates were recovered in an 18-month period. Although meat and clinical isolates belonged to the same sequence type, clonal spread and/or transmission from food to humans remains to be demonstrated. These findings underline the role played by an additional mechanism, apart from clonal spread of $\mathrm{O} 25 \mathrm{~b}: \mathrm{H} 4 / \mathrm{B} 2$ strains, of transmitting this gene in our area, i.e. dissemination within group A low-virulence strains via co-transfer within a multidrug resistance region in IncF plasmids. Further molecular analysis of 
food and human isolates will help to better define the epidemiology of CTX-M-15producing E. coli in our area.

\section{Funding}

This work was partially supported by the Ministerio de Ciencia e Innovación (Instituto de Salud Carlos III, Fondo de Investigación Sanitaria, REIPI- RD06/0008-1018, PS09/01273 and PI070190), the Ministerio de Educación y Ciencia (AGL-200802129), Junta de Andalucía (PI-0048/2008, P09-CTS-5259), Xunta de Galicia (09TAL007261PR, 2007/000044-0) and The European Regional Development Fund (ERDF). AM acknowledges the Ramón y Cajal programme from the Ministerio de Educación y Ciencia de España.

\section{Competing interests}

None declared.

\section{Ethical approval}

Not required. 


\section{References}

[1] Nicolas-Chanoine MH, Blanco J, Leflon-Guibout V, Demarty R, Alonso MP, Caniça MM, et al. Intercontinental emergence of Escherichia coli clone O25:H4ST131 producing CTX-M-15. J Antimicrob Chemother 2008;61:273-81.

[2] Rodríguez-Baño J, López-Cerero L, Navarro MD, Díaz de Alba P, Pascual A. Faecal carriage of extended-spectrum $\beta$-lactamase-producing Escherichia coli: prevalence, risk factors and molecular epidemiology. J Antimicrob Chemother 2008;62:1142-9.

[3] Doi Y, Paterson DL, Egea P, Pascual A, López-Cerero L, Navarro MD, et al. Extended-spectrum and CMY-type $\beta$-lactamase-producing Escherichia coli in clinical samples and retail meat from Pittsburgh, USA and Seville, Spain. Clin Microbiol Infect 2010;16:33-8.

[4] Blanco M, Alonso MP, Nicolas-Chanoine MH, Dahbi G, Mora A, Blanco JE, et al. Molecular epidemiology of Escherichia coli producing extended-spectrum $\beta$ lactamases in Lugo (Spain): dissemination of clone O25:H4-ST131 producing CTXM-15. J Antimicrob Chemother 2009;63:1135-41.

[5] Carattoli A, Bertini A, Villa L, Falbo V, Hopkins K, Threlfall EJ. Identification of plasmids by PCR-based replicon typing. J Microbiol Methods 2005;63:219-28.

[6] Lavollay M, Mamlouk K, Frank T, Akpabie A, Burghoffer B, Ben Redjeb S, et al. Clonal dissemination of a CTX-M-15 $\beta$-lactamase-producing Escherichia coli strain in the Paris area, Tunis, and Bangui. Antimicrob Agents Chemother 2006;50:2433-8.

[7] Eckert C, Gautier V, Arlet G. DNA sequence analysis of the genetic environment of various bla 
[8] Meunier D, Jouy E, Lazizzera C, Kobisch M, Madec JY. CTX-M-1 and CTX-M-15type $\beta$-lactamase in clinical Escherichia coli isolates recovered from foodproducing animals in France. Int J Antimicrob Agents 2006;28:402-7.

[9] Cortes P, Blanc V, Mora A, Dahbi G, Blanco JE, Blanco M, et al. Isolation and characterization of potentially pathogenic antimicrobial-resistant Escherichia coli strains from chicken and pig farms in Spain. Appl Environ Microbiol 2010;76:2799-805.

[10] Mora A, Herrera A, Mamani R, López C, Alonso MP, Blanco JE, et al. Recent emergence of clonal group O25b:K1:H4-B2-ST131 ibeA strains among Escherichia coli poultry isolates, including CTX-M-9-producing strains, and comparison with clinical human isolates. Appl Environ Microbiol 2010;76:6991-7.

[11] Sidjabat HE, Paterson DL, Adams-Haduch JM, Ewan L, Pasculle AW, Muto CA, et al. Molecular epidemiology of CTX-M-producing Escherichia coli isolates at a tertiary medical center in western Pennsylvania. Antimicrob Agents Chemother 2009;53:4733-9.

[12] Boyd DA, Tyler S, Christianson S, McGeer A, Muller MP, Willey BM, et al. Complete nucleotide sequence of a 92-kilobase plasmid harboring the CTX-M-15 extended-spectrum $\beta$-lactamase involved in an outbreak in long-term-care facilities in Toronto, Canada. Antimicrob Agents Chemother 2004;48:3758-64.

[13] Coque TM, Novais A, Carattoli A, Poirel L, Pitout J, Peixe L, et al. Dissemination of clonally related Escherichia coli strains expressing extendedspectrum $\beta$-lactamase CTX-M-15. Emerg Infect Dis 2008;14:195-200.

[14] Woodford N, Carattoli A, Karisik E, Underwood A, Ellington MJ, Livermore DM. Complete nucleotide sequences of plasmids pEK204, pEK499, and pEK516, encoding CTX-M enzymes in three major Escherichia coli lineages from the 
United Kingdom, all belonging to the international O25:H4-ST131 clone.

Antimicrob Agents Chemother 2009;53:4472-82.

[15] Manges AR, Tabor H, Tellis P, Vincent C, Tellier PP. Endemic and epidemic lineages of Escherichia coli that cause urinary tract infections. Emerg Infect Dis 2008;14:1575-83. 
Fig. 1. Xbal digestion pulsed-field gel electrophoresis (PFGE) dendrogram showing the relationship between the seven phylogroup A CTX-M-15-producing Escherichia coli isolates.

Fig. 2. Hybridisation of Hpal-digested plasmid profiles using (B) bla CTX-M-15 and (C) aac $\left(6^{\prime}\right)-I b$ probes associated with (A) Hpal-digested plasmid profile of transformants (E) or transconjugants (TC). Lane M, Hindll-digested $\lambda$; lane 1, O25:H4/ST131 B2 strain; lane 2, E281; lane 3, TC316; lane 4, E358; lane 5, E113-6; lane 6, E113-1; lane 7, E338; and lane 8, TC267. 
Edited Figure 1

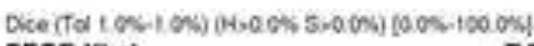

PFGE-Xbal PFGE-Xbal
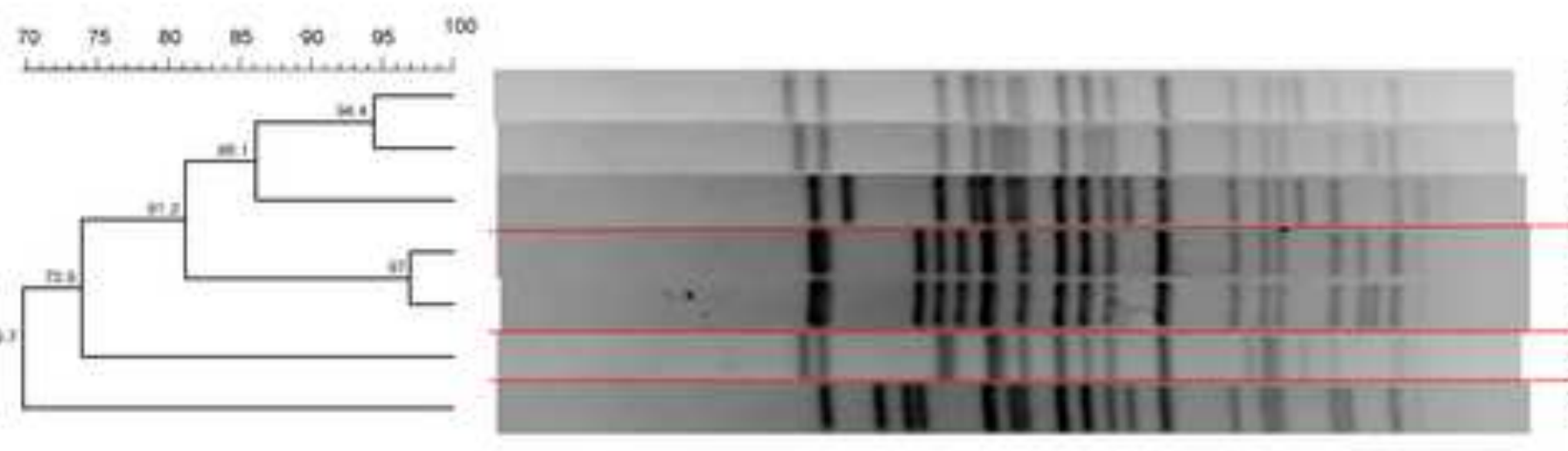

281

ONT:H9

27/09/2006

clinical

316 ONT:H9 25/10/2006 clinical

358 ONT:H9 05/12/2006 clinical

113-1 O55:H9 27/03/2007 meat

113-6 O55:H9 27/03/2007

meat

338 ONT:HNM $15 / 11 / 2006$ clinical

$267 \quad 020: 1+31 / 10 / 2005$ clinical

clinical IV. 


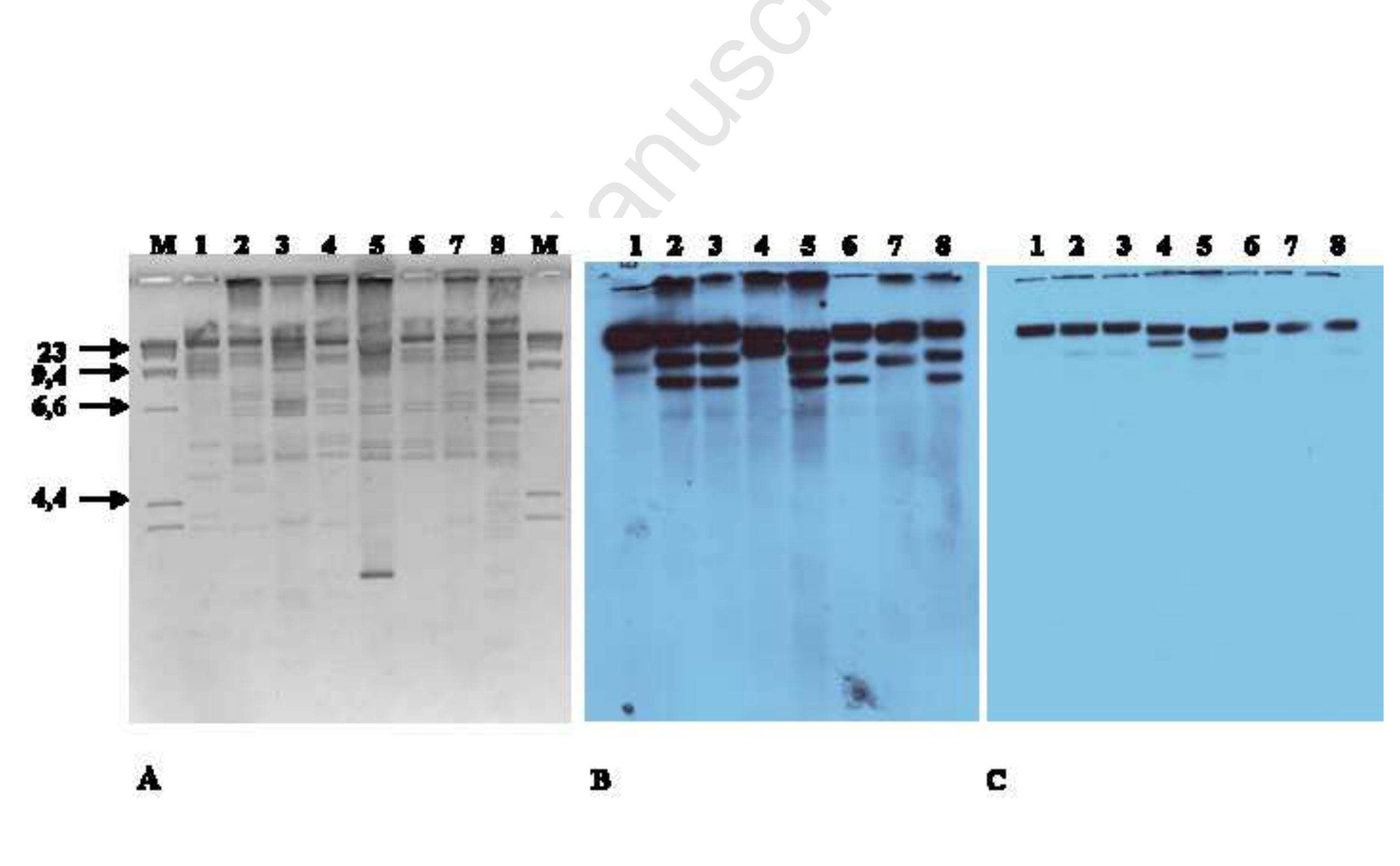

$\sqrt{2}+x^{2}$

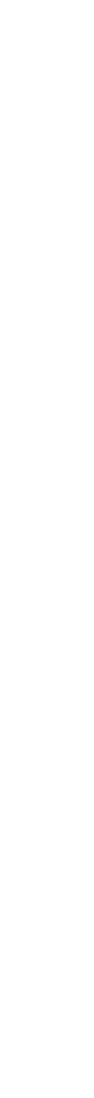

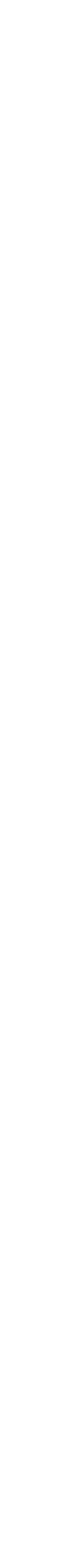

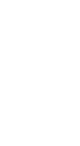

(1)

-

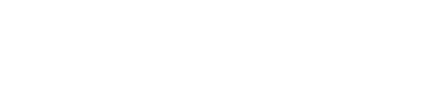

$+2$

